\title{
Evaluation of Cluster Front Line Demonstration on Black gram in Sawai Madhopur District of Rajasthan, India
}

\author{
Hukam Singh Kothyari ${ }^{*}$, K.C. Meena ${ }^{2}$, B.L. Meena ${ }^{3}$ and Ram Aseray ${ }^{4}$ \\ ${ }^{1}$ O.T.A. KVK, Sawai Madhopur, Agriculture University, Kota, Rajasthan, India \\ ${ }^{2}$ (Ag Extension) KVK, Sawai Madhopur, Agriculture University, Kota, Rajasthan, India \\ ${ }^{3}$ (Ag Entomology) KVK, Sawai Madhopur, Agriculture University, Kota, Rajasthan, India \\ ${ }^{4}$ KVK, Sawai Madhopur, Agriculture University, Kota, Rajasthan, India \\ *Corresponding author
}

\section{A B S T R A C T}

\begin{tabular}{|l|}
\hline Ke y w o r d s \\
$\begin{array}{l}\text { Front line } \\
\text { demonstration, Black } \\
\text { gram, Technology } \\
\text { gap, Seed yield }\end{array}$ \\
\hline Article Info \\
\hline $\begin{array}{l}\text { Accepted: } \\
\text { 12 December } 2017 \\
\text { Available Online: } \\
\text { 10 January } 2018\end{array}$ \\
\hline \hline
\end{tabular}

Krishi Vigyan Kendra Sawai Madhopur conducted Cluster Front Line Demonstration on Black gram variety Pratap Urd-1 at farmer plots in the two adopted village such as Sinoli and Kustla during Kharif 2017 under National Food Security Mission, Govt. of India. Fifty front line demonstrations conducted in 20 hectare area with active involvement of farmers and scientific staff of KVK. According to Analysis of data the highest grain yield was obtained in demonstrated plots with an average of $7.83 \mathrm{q} / \mathrm{ha}$ as compared to local check with an average of $5.77 \mathrm{q} / / \mathrm{ha}$. An average extension gap between demonstrated Practices and farmers practices was recorded $2.06 \mathrm{q} / \mathrm{ha}$ (Table 2). The net return $(23352 \mathrm{Rs} / \mathrm{ha})$ was obtained in the demonstration plots and 14263 Rs/ha was in local check plots. Benefit cost ratio was recorded higher in front line demonstrations (1.95) as compared to local check (1.31) during the period of Research study.

\section{Introduction}

Black gram (Vigna mungo) is a widely grown legume, belongs to the family Fabaceae and assumes considerable importance from the point of food and nutritional security in the world. It is a short duration crop and thrives better in all seasons either as sole or as intercrop. India is the world's largest producer as well as consumer of black gram. It produces about 1.5-1.9 MT of black gram annually from about $3.5 \mathrm{~m}$ ha. of area, with an average productivity of $600 \mathrm{~kg} / \mathrm{ha}$. Black gram output accounts for about 10 per cent of India's total pulse production. It is therefore, necessary to assess the technological gap in production and also to know the problems and constraints in adopting modern black gram production technologies Islam et al., (2011). Krishi Vigyan Kendra an innovative science based institution plays an important role in bringing the research scientist face to face with farmers. The main aim of Krishi Vigyan Kendra is to reduce the time lag between generations of technology at the research institution and its transfer to the farmers for 
increasing productivity and income from the agriculture and allied sectors on sustained basis. KVKs are grass root level organizations meant for application of technology through assessment, refinement and demonstration of proven produce technologies under different micro farming situations in a district (Das, 2007). The main objective of front line demonstration was to show the worth or value of the technology. The present investigation was undertaken to Evaluation of Cluster Front Line Demonstrations (CFLD's) on Black gram (Vigna mungo) in Sawai Madhopur district of Rajasthan.

\section{Materials and Methods}

The present study was carried out by Krishi Vigyan Kendra Sawai Madhopur and All 50 farmers from two Adopted villages were selected under Cluster front line demonstration. The soil of FLD's field was Alluvial soil and the $\mathrm{PH}$ of soil is near about 7.0- 7.5. The improved technology such as improved varieties, treatment of seed, Plant Protection measures was maintained during period of research study. Seed treatment is done with Bavistin $2 \mathrm{gm} / \mathrm{kg}$ of seed.

The seed rate of Black gram is kept $16 \mathrm{~kg} / \mathrm{ha}$ in demonstration plots. The sowing of Black gram crop seed was done during last week of June to first week of July. The spacing between Row and Plant was kept 30 x $10 \mathrm{~cm}$ for the cluster front line demonstration. The fertilizers doses were also given as basal dose. Two hands weeding with in Row were done at 30-35 and 55-60 days after sowing. The data were collected through personal contact with farmers at farmer's field and after that tabulated and analyzed to find out the findings and conclusion. The statistical tool like percentage used in this study for analyzed data. The extension gap, technology gap and the technology index were work out with the help of formulas given by Samui et al., (2000) as mentioned below:
Extension gap $=$ Demonstration yieldfarmers' yield (control)

Technology gap = Potential yielddemonstration yield

Technology index $=\frac{\text { Technology gap }}{\text { Potential Yield }}$

\section{Results and Discussion}

The findings of the present research study as well as relevant discussion have been conferred under following points:

\section{Yield performance}

The seed yield of CFLD's plots was higher as compared to local check which was due to good variety, seed treatment, plant protection measures were followed in CFLD's plots. The table 2 depicted that the average seed yield was $7.83 \mathrm{q} /$ ha which was higher as compared to local plots $(5.77 \mathrm{q} / \mathrm{ha})$.

The increased \% yield was 35.76 in CFLD's over local check. However, the obtained seed yield in CFLD's was low as compared to Potential yield of the variety Pratap Urd-1 due to drought like situation at the time of flowering and pod formation stage of the crop. The similar results were also observed by Dubey et al., (2010) and Poonia and Pithia (2010). Yield of the front line demonstration trials and potential yield of the crop was compared to estimate the yield gaps which were further categorized into technology and extension gaps (Hiremath and Nagaraju, 2009).

\section{Extension gap}

An average extension gap between demonstrated practices and farmers practices was recorded $2.06 \mathrm{q} /$ ha (Table 2). 
Table.1 Technology demonstrated in CFLD's and farmers' practices

\begin{tabular}{|c|c|c|c|}
\hline S. N. & Practice & Demonstrated practice & Farmers' practice \\
\hline 1. & Ploughing & 2 Ploughing & 1 Ploughing \\
\hline 2. & Variety & Pratap Urd-1 & Local Variety \\
\hline 3. & Seed Treatment & Bavistin@2g/kg seed & No seed treatment \\
\hline 4. & Seed Rate and Spacing & $16 \mathrm{~kg} / \mathrm{ha}$ and $30 \times 10 \mathrm{~cm}$ & $25-30 \mathrm{~kg} / \mathrm{ha}$ and $22 \times 7 \mathrm{~cm}$ \\
\hline 5. & Manures and Fertilizers & *NPK as basal dose $20: 40: 00 \mathrm{~kg} / \mathrm{ha}$ & $\begin{array}{l}\text { Use of NP as DAP mixing } \\
\text { with seed at sowing }\end{array}$ \\
\hline 6. & Weed control & $\begin{array}{l}\text { Cultural weeding and Sparay of } \\
\text { Imazithypar 10\% SL @ 55g/ha at 15- } \\
20 \text { DAS }\end{array}$ & $\begin{array}{l}\text { *No hand and cultural } \\
\text { weeding } \\
\text { *Over dose of herbicides }\end{array}$ \\
\hline 7. & $\begin{array}{l}\text { Plant Protection } \\
\text { Management }\end{array}$ & $\begin{array}{l}\text { *Pod borer: Quinalphos } 25 \text { EC @ } 1500 \\
\text { ml/ha. }\end{array}$ & $\begin{array}{l}\text { Injudicious use of } \\
\text { insecticides }\end{array}$ \\
\hline
\end{tabular}

Table.2 Productivity, extension gap, technology gap and technology index of black gram as grown under CFLD's and existing package of practices

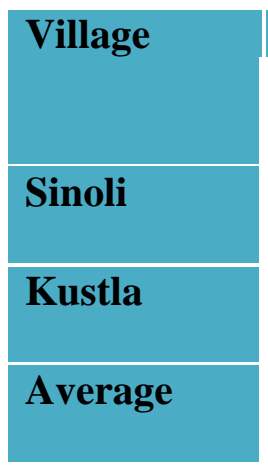

\begin{tabular}{|c|c|c|c|}
\hline \multicolumn{2}{|c|}{ Yield q/ha } & \multirow{2}{*}{$\begin{array}{l}\text { Increase yield } \\
\% \text { over control }\end{array}$} & \multirow{2}{*}{$\begin{array}{l}\text { Extension gap } \\
\text { (q/ha) }\end{array}$} \\
\hline Demons. & Local & & \\
\hline 7.86 & 5.75 & 36.69 & 2.11 \\
\hline 7.81 & 5.80 & 34.83 & 2.01 \\
\hline 7.83 & 5.77 & 35.76 & 2.06 \\
\hline
\end{tabular}

Technology
$\operatorname{gap}(\mathbf{q} / \mathbf{h a})$

2.14

2.19

2.17
Technology Index \%

21.40

21.90

21.65

Table.3 Gross Return, Net Return, Gross cost Cultivation and BC Ratio of black gram as grown under FLDS and existing package of practices

\begin{tabular}{|l|l|l|l|l|l|l|l|l|}
\hline Village & \multicolumn{2}{l|l}{$\begin{array}{l}\text { Gross cost of } \\
\text { Cultivation } \\
\text { (kg/ha) }\end{array}$} & \multicolumn{2}{l|}{ Gross Return(kg/ha) } & \multicolumn{2}{l|}{ Net Return(kg/ha) } & \multicolumn{2}{l|}{ BC Ratio } \\
\hline Demons. & Local & Demons. & Local & Demons. & Local & Demons. & Local \\
\hline Sinoli & 11988 & 10764 & 35440 & 26950 & 23452 & 16186 & 1.96 & 1.50 \\
\hline Kustla & 11988 & 10912 & 35240 & 27150 & 23252 & 12340 & 1.94 & 1.13 \\
\hline Average & 11988 & 10838 & 35340 & 27050 & 23352 & 14263 & 1.95 & 1.31 \\
\hline
\end{tabular}




\section{Histogram: Cluster front line demonstration and Field day in kustla village of Sawai Madhopur}

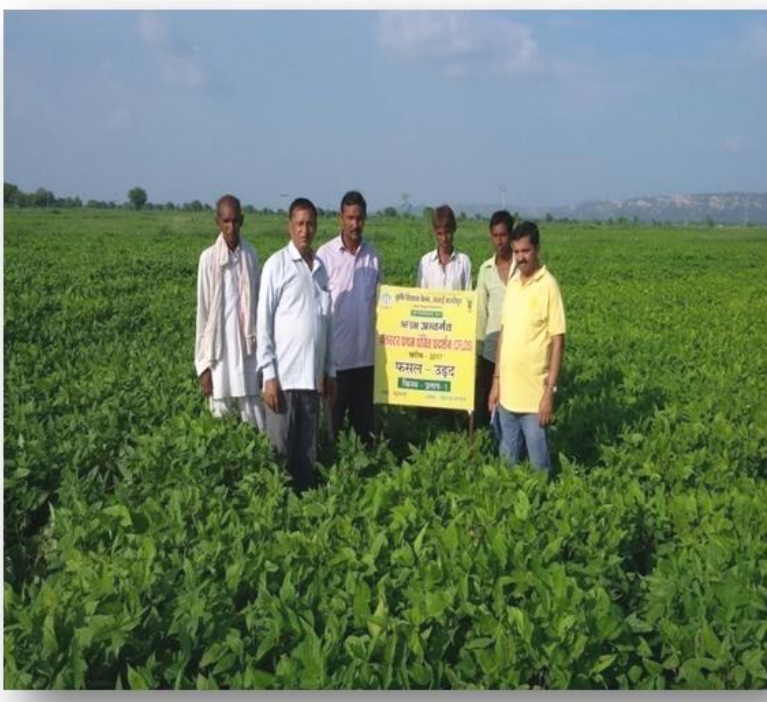

This Extension gap should be assigned to adoption of improved transfer technology in demonstrations practices which outcome in higher grain yield than the traditional farmer practices. The similarly observations were also obtained in Black gram crop by Bairwa et al., (2013) and also Hiremath and Nagaraju (2010).

\section{Yield gap and technology index}

Yield of the demonstration trails and potential yield of the crop was compared to estimate the yield gaps which were further categorized in to technology and extension gaps. The technology gap in the blackgram demonstration yield over potential yield was maximum $(2.165 \mathrm{q} / \mathrm{ha})$ observed during kharif 2017. The observed technology gap may be attributed dissimilarity in soil fertility status, rainfall distribution, disease and pest attacks as well as the change in the locations of demonstration plots every year. Further, the maximum extension gap of $2.06 \mathrm{q} / \mathrm{ha}$ was recorded in blackgram (Pratap Urd-1) demonstrations during kharif 2017. The table 2 also revealed that the technology index was 21.65 percent. The technology index shows the feasibility of the variety at the farmer's field. The lower value of technology index more

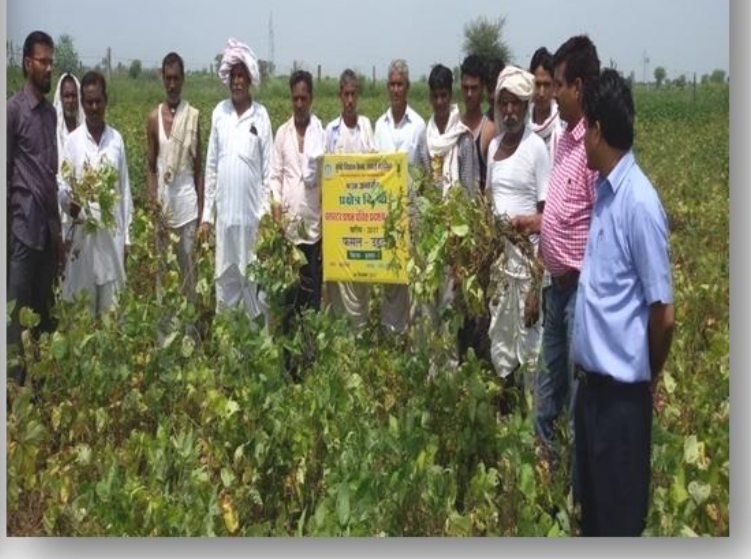

is the feasibility of technology. This indicates that a gap existed between technology evolved and technology adoption at farmer's field.

The similar results were also observed by Thakral and Bhatnagar (2002), Bairwa et al., (2013), Hiremath and Nagaraju, (2010) and Dhaka et al., (2010). Hence, it can be concluded from the table 2 that increased yield was due to adoption of improved varieties and conducting demonstration of proven technologies yield potentials of crop can be increased to greater extent.

\section{Economic return}

Cost of cultivation increased in demonstration practice (11988 Rs/ha) as compared to Local check (10838 Rs/ha). Use of pricy seeds for Crop sowing, seed treatment, recommended dose of Chemical fertilizers, Proper pest management etc, all of these are the main reasons for high cost of cultivation in demonstration plots than local check. The figures showed in Table 3 clearly explicated the implication of front line demonstration at farmer's field during the period of study in which higher net returns (23352 Rs/ha) were 
obtained under demonstration plots as compared to farmer practices (14263 Rs/ha). Benefit cost ratio was recorded under front line demonstrations (1.95) as compared to farmer practices (1.31) during the period of study. The similarly findings was also obtained by Bairwa et al., (2013).

The above results showed that the integration of improved technology along with active participation of farmer has a positive effect on increase the Grain yield and Economic return of Black gram crop Production. The suitable technology for enhancing the productivity of Black gram crop and need to conduct such demonstrations may lead to the improvement and empowerment of farmers.

High benefit: cost ratio also advocated the economic viability of the demonstration and motivated the farmers towards adoption of interventions demonstrated. Hence, by conducting front line demonstrations of proven technologies, yield potential of Black gram crops can be increased to great extent. This will subsequently increase the income as well as the livelihood of the farming community

\section{References}

Bairwa, R. K., S. R. Verma, K. Chayal and N. L. Meena 2013. Popularization of Improved Black gram Production Technology through Front line demonstration in humid southern plain of Rajasthan, Indian Journal of Extension Education and R.D. 21: 97-101.

Das Mamoni, Puzari N N and Ray B K 2010. Impact of training of skill and knowledge development of rural women, Agricultural Extension Review, 1(1): 29-
30.

Dhaka, B.L, Meena, B.S. and Suwalka, R. L. 2010. Popularization of improved maize technology through Frontline Demonstration in South-eastern Rajasthan, Journal of Agricultural Sciences, (1):39-42.

Dubey S, Tripathi S, Singh P and Sharma R K 2010. Yield gap analysis of black gram production through frontline demonstration, J Prog Agric 1(1): 42-44.

Hiremath S M and Nagaraju M V 2009. Evaluation of front line demonstration trials on onion in Haveri district of Karnataka, Karnataka J Agric Sci 22 (5):1092-1093

Hiremath SM and Nagaraju MV 2010. Evaluation of on front line demonstrations on the yield of chilli, Karnataka J. Agric. Sci., 23 (2): 341-342.

Islam M, Mohanty A K and Kumar S 2011. Correlation growth yield and adoption of urdbean technologies. Indian Research Journal of Extension Education, 11 (2): 20-24.

Poonia TC and Pithia MS 2011. Impact of front line demonstrations of chickpea in Gujarat, Legume Reeserach, 34(4): 304307

Samui, S.K., Maitra, S., Roy, D.K., Mondal, A.K. and Saha, D. 2000. Evaluation of front line demonstration on groundnut (Arachis hypogea L.) in Sundarbans, Journal of Indian Society of Coastal Agriculture Resources, 18(2): 180-183.

Thakral, S. K. and Bhatnagar, P. 2002. Evaluation of frontline demonstrations on Chickpea in north-western region of Haryana, Agric. Sci. Digest, 22 (3):217218.

\section{How to cite this article:}

Hukam Singh Kothyari, K.C. Meena, B.L. Meena and Ram Aseray. 2018. Evaluation of Cluster Front Line Demonstration on Black gram in Sawai Madhopur District of Rajasthan, India. Int.J.Curr.Microbiol.App.Sci. 7(01): 1569-1573. doi: https://doi.org/10.20546/ijcmas.2018.701.190 